\title{
Optimizing The Role of Zakat Management Organizations in Managing The Impact of The Covid-19 Pandemic in Indonesia
}

\author{
Elif Pardiansyah ${ }^{1 *}$, Muhammad Abduh², Muhamad Fakhrudin ${ }^{3}$ \\ $1^{*}, 2,3$ University of Sultan Ageng Tirtayasa, Indonesia \\ Corresponding Author: elfardianzyah@untirta.ac.id ${ }^{\left.1^{*}\right)}$
}

Keywords : Optimization,

Organization, Zakat.

\begin{abstract}
:
The Zakat Management Organization (OPZ) is an organization that is authorized or appointed by the government to collect, manage and distribute public funds related to zakat. Apart from having an impact on public health, the Covid-19 pandemic also has an impact on cross-sectors such as the economy, education and social humanity. The three sectors that are affected and are of concern to the government today are micro, small and medium enterprises (MSMEs), vulnerable workers, and business actors in the tourism sector. In dealing with this situation, the zakat management organization (POZ) is expected to have an important role in helping the government in handling Covid-19, especially in handling the poor or mustahik who have just been affected by Covid-19.
\end{abstract}




\section{Introduction}

Many are asking and predicting when this pandemic will end?. Some researchers state that the exact time this pandemic will stop cannot be estimated (Wan, 2020). However, Luo (2020) ensures that until the end of 2020 the world will still be at war against Covid-19 if there is no vaccine used in treating patients and changes in government policies and individual behavior, this is in line with predictions that a new vaccine will be found within 12 months. up to 18 months (Nugent, 2020).

The Covid-19 virus pandemic will not only have an impact on public health, it will also have an impact on people's social life, economic conditions, and finances. Groups of informal workers and vulnerable groups of poor will add to the new posture of Indonesia's poverty rate. The Center for Strategic Studies - the National Amil Zakat Agency (2020) projects that the poverty rate in areas that implement PSBB will increase compared to the previous period. This is reinforced by the argument of Suryahadi et al., (2020) in their article which states that if Indonesia's economic growth projection is $4.2 \%$ in 2020 , there will be an increase in the percentage of the poverty rate by $0.48 \%$ or equivalent to an increase of 1.3 million people. poor. This increase is even greater in line with the lower projection of Indonesia's economic growth 2020 . The toughest condition is when the projected economic growth reaches only $1 \%$, there will be 8.45 million new poor people in Indonesia.

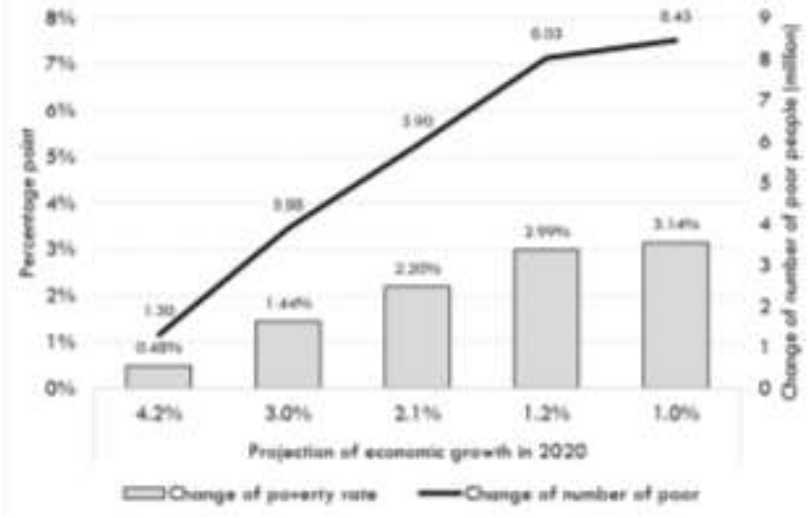

Source: (Suryahadi et al., 2020)

Figure 1. Changes in Poverty Levels and Number of Poor People

As a consequence, the central and regional governments must at least provide a social safety net, especially to deal with the poor and the new poor as a result of being affected by Covid-19. According to Kompas.com records (April 08, 2020) the government provides 7 social safety nets, including: Family Hope Program (PKH), Cash Intensive Work (PKT), Direct Cash Assistance (BLT), Basic Food Cards, Pre-Employment Cards, electricity subsidies for low-income groups. and special been converted into social assistance funds (Bansos) to deal with Covid-19. In addition, several 
social assistance for the Jabodetabek area. In addition, there are also Village Funds which have district/city local governments (Pemda) also provide assistance in the form of cash for their citizens who have not been touched by the 8 social safety nets above. In total there are 9 social safety nets and more than 430 trillion funds provided by the central and regional governments for their citizens who have been directly or indirectly affected by Covid-19 (Jawapos.com, 27 April 2020).

However, all of these government programs have not been able to resolve the problems due to the multidimensional impact of Covid-19. All social safety net programs that have been implemented by the government with the aim of securing the basic needs of the poor and affected poor. In addition to hitting the demand side or people's purchasing power (demand shock), Covid-19 also hit the production side (supply shock), especially MSMEs, so in the second period after the PSBB, the government needs to issue a program to stimulate the production side to operate again. One of them is through fiscal incentives for MSMEs and community empowerment programs, especially the poor.

This shows that cash transfer programs and community empowerment programs still need support from other sub-systems. Support from sub-systems other than the government is needed so that the benefits and reach of the recipient community are wider and more massive and can increase the benefit of the community. One of the sub-systems that can support the direct cash assistance program and community empowerment programs implemented by the government due to Covid-19 is by optimizing the Islamic social finance system, one of which is zakat. Zakat funds can be designated for the consumptive interests of the mustahik community, through the provision of cash or basic necessities, or in other primary forms, especially for the very poor (poor) and poor, as well as the new poor as a result of being affected by Covid-19. It can also be in the form of community empowerment programs in order to help the government stimulate the small, home, or individual business sector in terms of capital and other access.

Based on the various explanations above, it can be seen that the government's various social safety net programs in order to cope with the impact of Covid-19 are still unable to reach all levels of society affected by Covid-19, especially the new poor, thus requiring the active participation of other economic sub-systems. One of the sub-systems that will be discussed in this paper is the Islamic social finance system, namely the role of zakat in tackling the impact of Covid-19. Thus, the author tries to answer the question what is the role of zakat management institutions (POZ) in tackling the impact of Covid-19 in Indonesia?

\section{Research Method}

The method used in this study uses a case study method approach (case study method). The case study method is part of a qualitative method that wants to explore a particular case in greater depth by involving the collection of various sources of information (Raco, 2010). According to Creswell (1998) case studies are research in which researchers explore a particular 
phenomenon (case) in a time and activity (program, event, process, institution or social group) and collect detailed and in-depth information using various data collection procedures over a period of time. certain. Thus, in this study, the author seeks to explore the phenomena/cases that occurred due to Covid-19 and how the role of zakat management organizations (OPZ) in tackling this phenomenon.

\section{Result and Discussion}

The Covid-19 virus pandemic will not only have an impact on public health, it will also have cross-sectoral impacts on the economy, socio-economics, finance, and politics. This condition is predicted to last until the end of 2020 if a vaccine has not been found (Luo, 2020).

1. The Impact of the Covid-19 Pandemic on the National Economy

The Indonesian government in suppressing the spread of Covid-19 carried out two main options, namely conducting tests on people who had symptoms or were included in the spread cluster. In addition, the Indonesian government recently declared the implementation of PSBB or Large-Scale Social Restrictions in several provinces, districts and cities in Indonesia. The PSBB policy at least covers school and workplace holidays, restrictions on religious activities; restrictions on activities in public places or facilities; restrictions on social and cultural activities; restrictions on transportation modes; and restrictions on other activities. This policy has had a major impact on the Indonesian economy.

Social restrictions according to the World Bank (2020) cause a shock both from the demand and supply sides globally due to restricted activities. The Central Statistics Agency (BPS) noted that Indonesia's economic growth in the second quarter (Q2) 2020 experienced a contraction of minus 5.3\%. This figure worsened from the first quarter (Q1) 2020 where Indonesia's economic growth was still at 2.97 percent and the second quarter (Q2) 2019 of 5.05 percent. (Tirto, August $5,2020)$. This is far from the projection of Indonesia's economic growth based on the MediumTerm Development Plan, which is in the range of 5-6\%.

Various international economic bodies such as the World Bank estimate that this pandemic will erode national economic growth to only be in the range of $-3.5 \%$ to $2.1 \%$ in 2020 . In line with the World Bank, the IMF also projects Indonesia's economic growth of $0.5 \%$ in 2020 . This is clearly a sharp correction from the 5.02\% growth rate recorded in 2019 (Modjo, 2020).

Gopinath (2020) in Puskas Baznas (2020c) and Basri (Kompas, 8 June 2020) explained that the Covid-19 disease outbreak had hit the production side (supply shock) and the purchasing power side (demand shock). Gopinath (2020) predicts that economic uncertainty will create a phenomenon of salary reduction and panic that weakens the consumption of goods from the public. Such conditions can cause new socio-economic problems, including new poverty and new unemployment. According to BPS data (2019) data on poor people in Indonesia before the Covid19 pandemic (September 2019) was 24.79 million people (9.22\%). Some institutions estimate 
that there will be an additional 1.16 million $(+0.44 \%)$ to 9.6 million $(+3.6 \%)$ new poor people in 2020 , depending on the degree of economic damage that will occur.

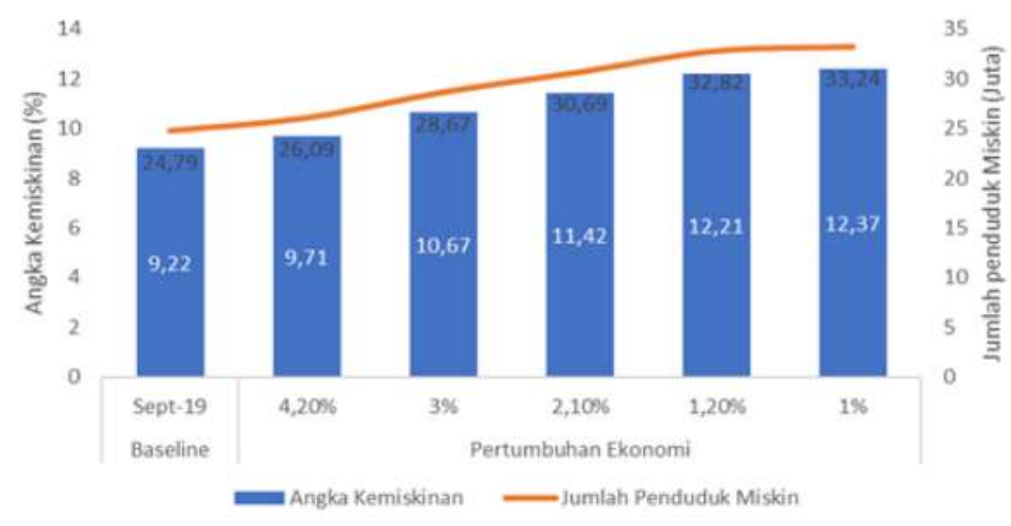

Source: Puskas Baznas, 2020b

Figure 2. Projected Impact of Covid-19 on Poverty Level

With a projected economic growth of $4.2 \%$ in 2020, there is an increase in the percentage of the poverty rate by $0.48 \%$ or equivalent to an increase of 1.3 million poor people. This increase is even greater in line with the lower projection of Indonesia's economic growth 2020. The toughest condition is when the projected economic growth reaches only $1 \%$, there will be 8.45 million new poor people in Indonesia. Meanwhile, in the first quarter, Indonesia's economic growth grew 2.97, meaning that according to the calculations of The SMERU Research Institute (2020) there was an increase in the percentage of the poverty rate by $1.45 \%$ or equivalent to an increase of 3.88 million new poor people.

2. The Impact of the Covid-19 Pandemic on the Workforce

From the workforce side, the main focus of the impact of COVID-19 is on 3 sectors, namely MSME business actors, vulnerable workers, and tourism business actors.

1) Impact on Micro, Small and Medium Enterprises (MSMEs)

Micro, Small and Medium Enterprises or MSMEs have a significant role in encouraging national economic growth. It is estimated that the number of workers working in this industry reaches 112 million workers with a market share of $95 \%$ and has a contribution of $57 \%$ to GDP (Gross Domestic Product) in 2018, or worth 457.3 trillion (Kemenkop, 2018). Referring to the data, it means that more than half of the national economic growth is supported by the MSME sector.

The government or KemenKUKM (Ministry of Cooperatives and SMEs) has not released official data regarding the impact of Covid-19 on losses in the MSME sector. However, if you look at the trend, the contribution of MSMEs to GDP will clearly decrease significantly, and the figure is projected to reach $23 \%$ or worth more than 1.6 trillion rupiah (Puskas Baznas, Polycy Brief: 05 March 2020d). The micro business sector is one of the sectors most vulnerable to economic slowdown due to the micro sector being a sector that 
has a fairly large market share for MSMEs, which is $98 \%$ or 63 million business units and absorbs 107 million workers (Kemenkop, 2018).

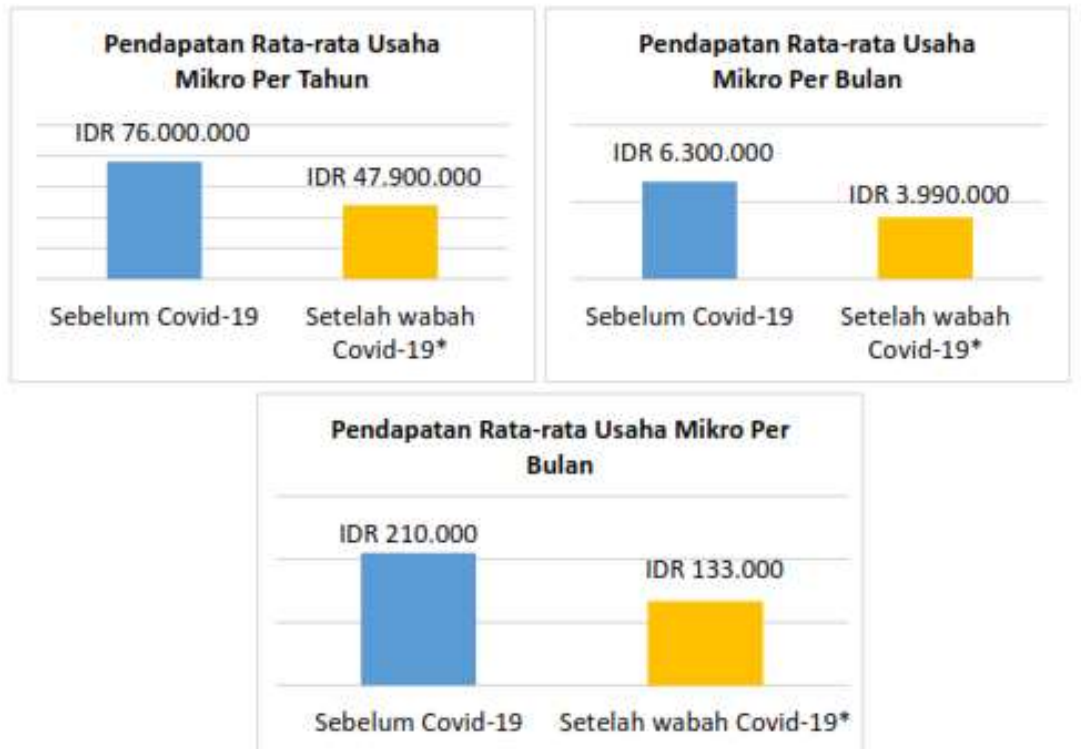

Source: Puskas Bazna, 2020d

Figure 3. Comparison of Micro Business Sector Income

In a normal situation without the Covid-19 outbreak, the income of the micro sector can reach Rp. 76 million per year or Rp. 6.3 million per month (Haryanti \& Hidayah, 2018). With the decline in income and turnover in the micro business sector caused by the Covid19 outbreak, there will be at least five risks that will be faced by the micro sector, namely increased production costs, decreased number of buyers, default on loans or credit, vulnerable to exposure to Covid-19, and the occurrence of layoffs (termination of employment) due to decreased production.

2) Impact on Vulnerable Workers

Based on data from the International Labor Organization (2014), Indonesia defines vulnerable work as self-employed, workers who help families, day laborers and entrepreneurs who are assisted by temporary workers/unpaid workers. Therefore, vulnerable workers have a high health and economic risk due to the extraordinary occurrence of Covid-19. The number of people who work in the informal and casual sectors is 74 million people or $57.2 \%$ (BPS, 2019) while the number of people who have vulnerable jobs is $46.68 \%$ or 60 million people of the total workforce in Indonesia (ILOSTAT, 2019 ). On the other hand, those who live below the poverty line are still 25 million people or $9.4 \%$ of the entire population of Indonesia (BPS, 2019).

Vulnerable workers are characterized by income below the minimum wage, low productivity and poor working conditions (ILO, 2014) making them sensitive to economic slowdown. In normal situations, the average income of workers in Indonesia is IDR 2.9 
million per month (BPS, 2019) or IDR 34.8 million per year. This means, if the situation worsens, economic growth is further corrected as happened in the second quarter (Q2), minus $5.32 \%$, then this group, which is approximately 60 million people, will find it increasingly difficult to survive and earn a living. Moreover, in general, not many vulnerable workers have life insurance, investments and savings for emergency funds in the face of economic shocks. Therefore, the expectation that many vulnerable workers will lose their jobs during the economic downturn due to the extraordinary event of Covid-19, will also increase the number of Indonesians living in the poverty.

3) Impact on Tourism Business Actors

The tourism sector is one of the sectors most affected by the Covid-19 pandemic. The tourism sector contributes at least 9\% to Indonesia's Gross Domestic Product (GDP). According to the Indonesian Institute of Sciences (LIPI), the MSME units in the tourism sector that are projected to be most affected by losses are the food and beverage business (27\%) and rattan wood crafts (17\%) (Puskas Baznas, 2020d).

In total, the tourism sector is predicted to lose more than $\mathrm{Rp} 22$ trillion. Furthermore, the Minister of Tourism and Creative Economy, Wishnutama, said that there are millions of jobs in the tourism sector, which are not limited to hotel, restaurant, event organizer (EO) units, or travel agencies, but also other informal units in the Tourism MSME sector. Worse yet, the impact of Covid-19 on the tourism sector could result in massive layoffs.

As information from the Central Statistics Agency (BPS) in 2020, the total population aged 15 years and over who work is 124 million people. This figure represents $67.26 \%$ of the total labor force participation rate. As for $11.7 \%$ of the total workers, or about 14 million people, are workers in the tourism sector. By taking at least a 20 percent decline in hotels due to Covid-19, then, at least 3 million people will lose their jobs and this figure represents the potential for new mustahik (zakat recipients) due to Covid-19.

3. The Role of Zakat Management Organizations in Preventing \& Dealing with Covid-19

Zakat is one of the obligations prescribed by Allah to Muslims, as an act of worship equivalent to prayer, fasting and pilgrimage. However, zakat is classified as maliyah worship, namely worship through wealth and not physical worship which is carried out physically (Arif, 2013). Therefore, zakat is different from other worship rituals, such as prayer, fasting, and hajj where the benefits are directly obtained by the individual alone. While the benefits of zakat can be felt not only by individuals who pay zakat but also other people who receive zakat benefits. Thus, the position and role of zakat in the Islamic social finance system is very important because it can achieve two strategic objectives, namely the purpose of worshiping Allah and social goals in the form of distributing zakat funds and empowerment through zakat funds.

According to Qhardawi (2007) linguistically, zakat is the basic word (masdar) zakkaa which means to grow, clean and good. Meanwhile, according to Al-Utsaimin (2008) zakat according to 
language is increasing and developing. According to him, in language, anything that increases in number or grows in size is called zakat. An explanation of zakat in language is also stated in the book Zakatnomics: Study of Basic Concepts, zakat comes from the words zakkaa - yuzakkii tazkiyatan - zakaatan which can mean: at-thohuru (cleaning or purifying), al-barakatu (blessing), an-numuw ( grow and develop), and as-sholahu (settle or order) (Center for Strategic Studies National Amil Zakat Agency, 2019). This meaning is also found in the expression of Ali bin Abi Talib: "wealth will decrease if it is shared, while knowledge will increase if it is shared (infaq)".

As a social institution, zakat management organizations (OPZ) have an important and strategic role to assist the government in preventing and dealing with the Covid-19 pandemic. OPZ through education, distribution and utilization programs can take strategic steps to assist the government in preventing the spread of Covid-19.

1) Role in the economy

The impact of Covid-19 on the weakening of the world economy will certainly open up the potential for the birth of new mustahik. In a global context, zakat management organizations (OPZ) can collaborate with WZF (World Zakat Forum) to discuss opportunities for zakat distribution for the prevention, treatment, and research of Covid-19 vaccines (Hudaefi et al., 2020). In the national and local context, the distribution and distribution of zakat in the economic field can be developed towards empowering new mustahik caused by weak global economic growth due to Covid-19. The new mustahik in question can be broken down from 8 asnaf beneficiaries of zakat who are affected by Covid-19 such as new poor people, new poor people, gharimin (people in debt) due to layoffs or business out of business, and fii sabilillah such as teachers/lecturers. honorary, Koran teachers, boarding school administrators, etc.

2) Role in the field of education and social humanity

In the midst of the Covid-19 pandemic, OPZ plays an active role in various fields, including in the fields of education, social and humanity. OPZ is required to be able to play more roles, namely by widening its reach and role. For example, OPZ can distribute infaq funds for preventive measures (prevention) in preventing this virus from the individual level, as has been implemented by many OPZs at the beginning of this pandemic found in Indonesia.

Furthermore, contributions in related fields have also been made by distributing masks (face shields) in public places. In a specific role in the field of education, OPZ has done a lot of counseling about the dangers of Covid-19. This kind of role has been carried out by OPZ, both internally OPZ at the beginning of the pandemic, as well as directly entering the general public, such as visiting schools, campaigning around using ambulances, and so on.

3) Role in the field of employment/business actors

MSME actors, vulnerable workers, and small workers in the tourism sector certainly need help in order to minimize the economic impact they feel. Related to this, the government has also provided various kinds of economic stimulus and appeals for layoffs not to be carried out for small workers. 
For vulnerable workers such as fishermen, motorcycle taxi and taxi drivers, President Joko Widodo has also issued a similar policy in the form of deferring credit payments for one year (Taher, 2020). Direct Cash Assistance (BLT) will also be given to informal workers who have to stay at home due to the effects of COVID-19 (Putri, 2020). One of the parties that can help the government in this regard is the Zakat Management Organization or OPZ. According to Law no. 23 of 2011 concerning Zakat Management, one of the functions of OPZ is to distribute zakat funds to people who are included in the mustahik group.

The Covid-19 pandemic has changed everything. The status of vulnerable workers and micro-enterprises who were initially not included in the category of recipients of zakat funds (mustahik), many of whom changed their status to become mustahik of zakat funds (into category 8 asnaf). This is because their activities in earning a living are disrupted, hampered, temporarily suspended, and even lost due to the Covid-19 pandemic, so that they suddenly cannot fulfill their daily needs (below the poverty line). This incident made them a new poor group where the group was included in the ashnaf category who were entitled to zakat assistance. Therefore, the role of OPZ becomes increasingly important to meet the needs of those in need, such as vulnerable workers, MSME actors and small workers.

The role of zakat institutions in distributing ZIS funds (Zakat, Infaq and Sadaqah) has a strategic position in helping the economy of vulnerable workers. Zakat institutions are expected to prioritize consumptive zakat over productive zakat at this time. This is in line with Alatas' opinion in (Agustiyanti, 2020) who proposed direct cash assistance (BLT) as a fiscal stimulus to potentially affected residents because BLT is expected to boost people's purchasing power. On this side, zakat institutions can assist the government in reaching those who are affected but have not been touched by the assistance program as a social safety net issued by the government.

The pandemic creates conditions where a person has a source of income but the income earned is still very small so that they are unable to meet their daily needs. Basically poverty and poverty are problems with a multidimensional framework that can be seen from various sides. The existence of poverty and poverty is not only related to the size of income, but also concerns the vulnerability and vulnerability of people or communities to be poor. Which is because there is no fulfillment of the basic rights of individuals or communities in living life. On the other hand, unproductive community activities can cause some people to fall into debt, both for personal use and for guaranteeing for social purposes. Looking at this phenomenon, the gharim provisions can be used as an excuse that zakat must be distributed to such community groups. Gharim according to the school of Abu Hanifah is a person who has debt and assets owned are not sufficient to meet the debt. (Puskas Baznas, 2017b).

Regarding assistance to micro-enterprises, OPZ can assist the government, relevant ministries, and other stakeholders through strengthening or providing business capital assistance, mentoring, relaxation of credit or loan maturity, providing access to markets and 
providing protection in the form of counseling and insurance provision for sector entrepreneurs. micro on the possibility of being infected with Covid-19. These efforts are expected to minimize the negative impact of the COVID-19 outbreak on the Micro business sector, which is the economic foundation for most low-income people.

As for business actors in the tourism sector, in the context of new mustahik, OPZ can distribute and distribute consumptive zakat distribution for groups directly affected by the sluggish tourism sector, especially small traders in coastal tourism areas.

\section{Conclusion}

Indonesia is the 65th country affected by COVID-19. The virus has spread in all provinces in Indonesia. The negative impact of Covid-19 is something that cannot be avoided by any country for now, including Indonesia. Based on data from the Task Force for the Acceleration of Handling Covid-19, Covid-19 cases, both total cases, new cases, and deaths due to COVID-19 continue to grow and increase. Therefore, the government's priorities are currently divided into two, namely protecting public health while anticipating an economic slowdown by issuing various programs and policy packages.

In carrying out its duties, the government needs assistance from various other parties. One of the parties that can carry out this task is the Zakat Management Organization (OPZ), considering that this institution has a network in every province and district/city throughout Indonesia, qualified amil resources, as well as zakat, infaq, and alms (ZIS) funds that can be used to help disadvantaged communities affected by Covid-19. In addition to the health and economic sectors, there are three sectors that are affected and are currently of concern to the government, namely micro, small and medium enterprises (MSMEs), vulnerable workers, and business actors in the tourism sector.

Thus, Zakat Management Organizations (OPZ) are encouraged to prioritize the distribution of zakat, infaq, and alms (ZIS) funds in an effort to handle the Covid-19 crisis, such as the provision of Personal Protective Equipment (PPE) for medical staff/paramedics/health volunteers, provision of ambulances, providing Covid-19 volunteers, and cash for work and so on. In addition, zakat institutions throughout Indonesia have established a direct cash assistance program or Mustahik Cash Assistance (BTM) for the poor/victims of layoffs due to the Covid-19 crisis..

\section{References}

Ali, M. Daud. (1988). Sistem Ekonomi Islam Zakat dan Wakaf, Jakarta: Universitas Indonesia (UIPress).

Al-Utsaimin, S. M. S. (2008). Ensiklopedi Zakat. Pustaka As-Sunnah.

Arif, M. N. R. Al. (2013). Optimaslisasi Peran Zakat Dalam Memberdayakan Perekonomian Umat. Ulul Albab, 14(1), 1-15. 
Dani Prabowo. 08 April 2020. 7 Jurus Sakti Pemerintah untuk Jaring Pengaman Sosial Atasi Dampak Covid-19. Diakses dari https://nasional.kompas.com/read/2020/04 108/11471681/7-jurus-sakti-pemerintah-untuk-jaring-pengaman-sosial-atasi-dampakcovid-19.

Departemen Ekonomi dan Keuangan Syariah - Bank Indonesia. (2016). Pengelolaan Zakat yang Efektif: Konsep dan Praktik di Beberapa Negara (Seri Ekono). Departemen Ekonomi dan Keuangan Syariah - Bank Indonesia.

Estu Suryowati. 27 April 2020. Pengamat Sarankan Anggaran Jaring Pengaman Sosial Ditingkatkan. Diakses dari https://www.jawapos.com/ekonomi/27/04/2020/ pengamatsarankan-anggaran-jaring-pengaman-sosial-ditingkatkan.

Fadillah, S., Lestari, R., \& Rosdiana, Y. (2017). Organisasi Pengelola Zakat (OPZ): Deskripsi Pengelolaan Zakat Dari Aspek Lembaga Zakat. Kajian Akuntansi, 18(2), 148-163.

Huda, Nurul. (2012). Zakat dalam Pendekatan Kontemporer. Jurnal Probisnis, 5(1).

Hudaefi, F. A., Junari, U. L., Zaenal, M. H., \& Ramdhoni, R. (2020). Mencegah COVID-19: Apa Peran Organisasi Pengelola Zakat? Badan Amil Zakat Nasional, February, 1-10. https://doi.org/10.13140/RG.2.2.23370.11207

Manan, M. A. (1995). Teori dan Praktek Ekonomi Islam, penerjemah M. Nastangin, Yogyakarta: PT. Dana Bhakti Wakaf.

Modjo, M. I. (2020). Memetakan Jalan Penguatan Ekonomi Pasca Pandemi. The Indonesian Journal of Development Planning, IV(2), 103-116.

Qhardawi, Yusuf. (2007). Fiqh Zakat. Jakarta: Mizan.

Raco, J. R. (2010). Metode Penelitian Kualitatif. Jakarta. Jakarta: PT Gramedia Widiasarana.

Sabiq, Sayyid. (2009). Fikih Sunnah Jilid 2. Jakarta: Cakrawala Publishing.

Pusat Kajian Strategis - Badan Amil Zakat Nasional. (2020b). Laporan Baznas Dalam Penanganan Pandemi Covid-19.

Pusat Kajian Strategis - Badan Amil Zakat Nasional. (2020c). Puskas Working Paper Series: Pembangunan Ekonomi Sosial Berbasis Wilayah Dalam Kasus Pembatasan Sosial Akibat Krisis Covid-19 Indonesia 2020.

Pusat Kajian Strategis - Badan Amil Zakat Nasional. (2020a). Ketentuan dan Tata Cara Penghitungan Zakat Profesi.

Pusat Kajian Strategis - Badan Amil Zakat Nasional. (2017a). Fiqih Zakat Keuangan Kontemporer. Puskas Baznas.

Pusat Kajian Strategis - Badan Amil Zakat Nasional. (2017b). Zakat Untuk Kemandirian Ummat Melalui Pemberdayaan Masyarakat. Puskas Baznas.

Pusat Kajian Strategis - Badan Amil Zakat Nasional. (2019). Zakatnomics: Kajian Konsep Dasar. 
Suryahadi, A., Al Izzati, R., \& Suryadarma, D. (2020). The Impact of COVID-19 Outbreak on Poverty: An Estimation for Indonesia. In The SMERU Research Institute: Vol. April.

The SMERU Research Institute. (2020). The Impact of COVID-19 Outbreak on Poverty: An Estimation for Indonesia.

Unicef. (2020). Covid-19 dan Anak-anak di Indonesia (Issue April).

Uyun, Q. (2015). Zakat, Infaq, Shadaqah, Dan Wakaf Sebagai Konfigurasi Filantropi Islam. Islamuna: Jurnal Studi Islam, 2(2), 218. https://doi.org/10.19105/islamuna.v2i2.663

Vincent Fabian Thomas. 5 Agustus 2020. Pertumbuhan Ekonomi RI Q2 2020 Minus 5,32\%, Terburuk Sejak 1999. Disadur dari Tirto pada tanggal 6 Agustus. 